\title{
THE DISTRIBUTION OF DIVINE NAMES IN JONAH
}

By F. D. KIDNER

In this book of 48 verses no other divine terms beside Yahweh and Elohim are found, with the exception of El, which occurs once at 4:2 (in a quotation from Ex. 34:6). A simple count gives 25 occurrences of Yahweh and 15 of Elohim; but the latter divide into 8 examples in which Elohim is used absolutely, and 7 in which it is qualified by grammatical relation with a person or sphere, or with the name Yahweh.

Apart from one instance $(4: 6)$, there is nothing unusual about the non-absolute occurrences of Elohim. Some refer to a god in the heathen sense $(1: 5,6,6)$, the rest to Yahweh as God of heaven ( $1: 9)$ or as Jonah's God (2:1 (MT 2), $6(M T$ 7)). In $4: 6$, however, there is a rarity, the composite name Yahweh Elohim, which is a feature of Genesis 2 and 3, but found elsewhere only 8 times in all.

If some principles are discernible in these usages they could possibly throw a little light on the larger question of their distribution in the Pentateuch.

Perhaps three things emerge:

a. A preference for 'Tahweh' in an Israelite context and 'Elohim' elsewhere. Chapters $\mathrm{r}: \mathrm{I}-4: 5$ could be a textbook example of this rule, since the name Yahweh is in sole possession of the opening episodes, which concern the prophet's adventures, occurring I9 times in the 30 verses $I: I-3: 3$, but is immediately replaced by 'Elohim' (used absolutely) in 3:5-10 ( 5 occurrences), where Nineveh repents of its 'evil way' and its 'violence' $(3: 8)$ in response to a divine but not specifically Yahwistic message. As soon as Jonah regains the limelight, the name Yahweh reappears, dominating $4: 1-4$.

b. Limits to this preference. The pattern breaks up at $4: 6$, where with 'Yahweh Elohim' the two terms stand together, after which 'Elohim' has dealings with Jonah (7-9) which 'Yahweh' completes (Iof.). No theological motive is apparent 
here, for the terms cut across the expected boundaries. 'Yahweh Elohim' could be an evocation of Genesis 2, a passage possibly relevant to the miraculous provision of the sheltering plant; yet this is merely the second special providence in a series of four, of which 'Yahweh' was designated the author of the first (I:I7 (MT 2:I)), and 'Elohim' that of the last two (4:7, 8). Again, Jonah's estrangement from the LORD might be thought to be emphasized by the change to the more distant term Elohim in 4:7-9, were it not that the name Yahweh reappears in 4:10 immediately after Jonah's second and stronger outburst. Even the question 'Do you do well to be angry?' is prefaced once by 'Yahweh' and once by 'Elohim'.

At this point the suspicion may arise that the authorship of Jonah is composite, or its text disturbed. Both views have been taken. The most thoroughgoing source-analysis was that of W. Böhme in 1887 , who postulated at least five contributors: a Yahwist, an Elohist, an Elohistic Redactor, a Yahwistic supplementer and one or more glossators. While this conclusion was too elaborate to command support (and incidentally suffered the embarrassment of having to attribute the Elohim verses, $4: 7,9$, to the Yahwist), similar attempts have been equally unable to win favour, and the consensus is that the book cannot be parcelled out among Yahwistic and Elohistic authors.

The text of 4:7ff., however, in the ancient versions, shows some divergences from the $M T$ in the terms used for God. While the Lxx agrees with $M T$ over these terms throughout this section, Codex Alexandrinus, Codex Marchalianus and a few of the cursive MSs of the LXX add or substitute reveros at some points in these verses where $\theta$ cós is otherwise found. The Old Latin and the Vulgate show the same tendency, and the Peshitta gives the equivalent of Yahweh Elohim throughout 6-9.

J. A. Bewer (ICC, I9I2) uses these data not as direct evidence of what stood in the earliest Hebrew text, but as indications of the direction in which copyists (including, by inference, copyists of the pre-Massoretic text) tended to corrupt this passage. Some translators and copyists of the Versions, coming to the unexpected word 'God' in 4:6-9, seem to have yielded to the pull of 'Lord', from the verses before, and substituted or 
added it. 'The process', says Bewer, 'was the same in Heb. MSs. . . . Our author did not write [Yahweh Elohim in verse 6], he wrote simply יהוה. A copyist, or reader, under the influence of ch. 3 wrote probably all through ch. 4 , but in some instances the orig. readings reasserted themselves.'

But this reasoning is most precarious. Not only does Bewer: reverse the direction of change (which ran from 'God' to 'Lord' in the versions, but from 'Lord' to 'God' in this reconstruction of the Hebrew), but he extends the supposed corruption to the whole chapter before wiping out its traces in all but verses 6-Io. This he has to do, to make the postulated intrusion of 'Elohim' plausible; but his theory has outrun his data.

We are brought, it seems, back to the $M T$, with a heightened recognition of the author's occasional independence of his general procedure. This establishes as our third finding:

c. The author's literary freedom. On the evidence as we have it, the book of Jonah shows a responsible but not hidebound attitude to the distinctions implied in its two main terms for God. On the whole (and this means for more than nine-tenths of the book) the theme of Israel and the Nations closely controls the choice of one term or the other as appropriate to the more intimate or the more general relationship of God to man. To a large extent this rationale can be discerned in Pentateuchal usage as well. But the purely aesthetic impulse towards variety of language also asserts itself, freeing the narrator from undue bondage to his rules, and at the same time reminding the reader that the names are in the last resort interchangeable, common to the one Yahweh Elohim. And this too is not irrelevant to Pentateuchal studies. 